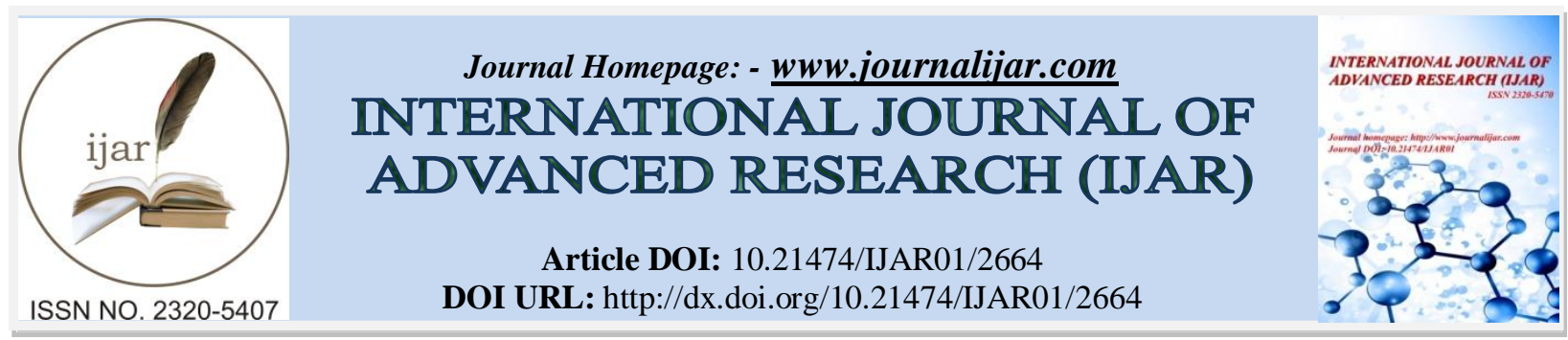

RESEARCH ARTICLE

\title{
A CLINICAL STUDY OF SANDHIGATAVATA WITH THE EFFECT OF PANCHAMULADI KSHIR BASTI.
}

Dr. H. S. Bhivgade and Vidya Shivram Boinwad.

Kayachikitsa Department, Govt.Ayurved College, Nanded.

\section{Manuscript Info}

Manuscript History

Received: 31 October 2016

Final Accepted: 30 November 2016

Published: December 2016

Key words:-

sandhigatavata ,panchamuladi kshir, basti .,osteoarthritis.

\section{Abstract}

Sandhigatavata is very common clinical condition of old age especially during $4^{\text {th }}$ and $5^{\text {th }}$ decade of life. It is particularly a degenerative disorder caused by vitiation of vata. Sandhigatavata is described in Bruhat trayies .Acharya charak has described Sandhigatavata with signs and symptoms like Vatapurnadritisparsha(creapitation in knee joint)Sshotha(swelling) Pprasaran Sakunchan Savedana(painful flexion and exetention) ${ }^{1}$ in modern system of medicine it is closely resembles with Osteoarthritis, which is due to destruction of articular cartilage ,synovial fluid and synovial activity of large joints, it limits daily activity such as walking dressing etc ${ }^{2}$. Prevalence of osteoarthritis in India is reported to be in the range of $17-60.6 \%{ }^{3}$..In modern medicine, mainly Analgesics, Non steroidal anti-inflammatory drugs or surgery are the options for the management of osteoarthritis. These don't give satisfactory relief and also cause adverse effect. Ayurveda has a ray of hope to such patients because of its holistic approach of cure and prevention of disturbances in physiology. Acharya Charak has stated the management of Asthyashrit vyadhi by panchakarma specially Basti,Kshir Ghrita and Sneha ${ }^{4}$ Kshir processed with Bruhat Panchamula and BalaPanchamuladi kshir) is described in Chakradatta for the managemaent of Vatavyadhi ${ }^{5}$ considering above reference panchamuladi kshir was selected in the form of Basti in experimental group and in control group Sandhigatvata was treated by Rasnadi Guggul .The study showed significant result in experimental group as compare to control group.

Copy Right, IJAR, 2016,. All rights reserved.

\section{Introduction:-}

Ayurveda is the science of life and longevity. In Ayurveda, Sandhigatavata described in all Samhita Granthas.In Sandhigatavata, Sandhi denotes the Adhishthana of Vyadhi and Vata denotes the Dosha of Vyadhi.the signs of symptoms of Sandhigatavata is Shotha (swelling) Vatapurnadritisparsha (crepitation ), Sandhishotha (swelling), Prasaran Akunchan Svedana (difficulty in flexion and exteention) described by Acharya Charaka.Sushrut described Sandhigatavata in Nidan Sthana as Hantisandhi (destroy of joint),Sandhishula(joint pain) and Sandhi shotha $a^{6 .}$ These signs and symptoms of Sandhigatavata closely resembles with Osteoarthritis which is due to destruction of articular cartilage, synovial fluid and synovial cavity of large joints. Most commonly affected joints are knee joints .It limits daily activities such as walking, dressing, etc. 
In modern science, mainly analgesics, Non steroidal anti inflammatory drugs or surgery are options for the management of Osteoarthritis. These treatments don't give satisfactory relief and also causes some adverse effects Ayurveda has a ray of hope to such patients because of its holistic approach of cure and prevention of disturbance in physiology. Sandhigatavata is one of the Ashtyashrit vyadhi.Acharya charak has stated the management of Asthyashrit vyadhi by

Panchakarma specially Basti,Kshir,Sneha .Kshir processed with Bruhat panchamula and Bala is described in Chakradatta for the management of Vatavyadhi.considering above reference Panchamuladi kshir was selected in the form of basti for the Sandhigatavata.this study was divided into two groups. In experimental group,30 patients of sandhigatavata were treated with Panchamuladi kshir Basti was given in morning in the dose of $120 \mathrm{ml}$ for thirty days after some food. In control group, 30 patients of Sandhigatavata were treated with Rasnadi Guggul in the dose of 500mg two times for six weeks.

The result of the study showed that Panchamuladi Kshir provides better results in Sandhigatavata as compare to Rasnadi Guggul. In case of symptoms, significant results were found in treated group as compare to control group. Angle of flexion was significantly increased in treated group and also ESR was significantly decreased in treated group .So it was concluded that the result of Panchamuladi kshir were better compare to Rasnadi Guggul.

\section{Aims and objectives:-}

* To study the effect of Kshir Basti processed with Brihit panchamula and bala in case of sandhigatavata (panchamuladi kshir basti).

* To asses the effect of basti clinically

* To study the Sandhigatavata through ayurvedic texts and osteoarthritis through modern text.

* To compare the effect of Kshir basti with Rasnadi Guggul.

\section{Materials and Methodes:-}

Criteria for selection of patient:-

For this study patient were selected from OPD/IPD department of kayachikitsa of our institute .The patient having signs and symptoms of Sandhigatavata were randomly selected irrespective of age, sex, caste, religion, economical and educational status. The necessary investigation were carried out to exclude the patients described in rejection criteria.

\section{Criteria for rejection of patient:-}

* The patients having Samavastha were rejected.

* The patients having fixed joints or had developed contractures were not included in the study.

* The patients who were depending upon steroids and some analgesics drugs were also excluded from the study.

* The patients who had signs and symptoms of rheumatoid arthritis, gonococal arthritis, syphilitic arthritis, pyogenic arthritis were rejected from this study.

* The patients who had signs and symptoms of Amvata, Vatarakta,Kroushtukshirsha were also rejected

* Overweight patients were excluded from this study.

\section{Plan of work:-}

* Dignosed patients were divided into treated group and control group.

* TREATED GRROUP-In this group 30 patients were treated with Panchamuladi Kshir Basti .Kshir was prepared as Kshirpaka method mentioned in Sharangdhar Samhita. The process of Basti chikitsa Was strictly followed .Freashly prepared Kshir was used for Basti.

Panchamuladi kshir contains:-

Bilva ,Agnimantha, ,Shyonak,, Gambhari, Patala, Bala ,Kshir and Ghrita

\section{Preparation of panchamuladi kshir:-}

The contains of Panchamuladi Kshir Basti were brought from market the process for preparation of Kshirpak was followed by Sharangdhar Samhita ${ }^{7}$.

Dose- $120 \mathrm{ml}$

Duration-30 days 


\section{Control group:-}

In control group, Rasnadi Guggul was given to 30 patients. The contains of Rasnadi Guggul -Rasna (pluchea lanceolata),Guduchi(tinosporacordifolia)Erandmula(recinus communis),Devdaru(cedrus deodara),Shunthi(zingiber officinalis),Shuddha Guggul described in Yogratnakar.Rasnadi Guggul was given to the patients in control for 6 weeks in the dose of $500 \mathrm{mg}$ two times a day. Rasnadi guggul was prepared in Ras shastra department of our institute under guidance of of head of the department.

\section{Criteria of Assesment:-}

The main criteria of assessment in this study were based on the symptom score before and after treatment(symptoms included pain ,pain on extention and flexion, stiffness, Shotha in joint, crepitus, tenderness, nature of pain, Dosha and Dushya Dushti, roentginological gradation)

Angle of flexion of knee joint before and after treatment was done

Routine blood investigations,erythrocyte sedimentation rate was done before and after treatment.

Observation and Results:-

\begin{tabular}{|c|c|c|c|c|c|c|}
\hline \multirow{2}{*}{$\begin{array}{l}\text { SR } \\
\text { NO }\end{array}$} & \multirow{2}{*}{ SYMPTOMS } & \multirow{2}{*}{ GROUP } & \multicolumn{3}{|c|}{ SYMPTOM SCORE } & \multirow{2}{*}{$\begin{array}{l}\text { PERCENTAGE } \\
\text { OF RELIEF }\end{array}$} \\
\hline & & & BT & AT & DIFF & \\
\hline \multirow[t]{2}{*}{1} & \multirow[t]{2}{*}{ Pain } & $\begin{array}{l}\text { Treated } \\
\text { group }\end{array}$ & 127 & 21 & 106 & $83.46 \%$ \\
\hline & & $\begin{array}{l}\text { Control } \\
\text { group }\end{array}$ & 129 & 48 & 43 & $33.33 \%$ \\
\hline \multirow[t]{2}{*}{2} & \multirow[t]{2}{*}{$\begin{array}{l}\text { Pain on extention and } \\
\text { flexion }\end{array}$} & $\begin{array}{l}\text { Treated } \\
\text { group }\end{array}$ & 96 & 29 & 67 & $69.79 \%$ \\
\hline & & $\begin{array}{l}\text { Control } \\
\text { group }\end{array}$ & 115 & 92 & 23 & $20.00 \%$ \\
\hline \multirow[t]{2}{*}{3} & \multirow[t]{2}{*}{ Stiffness } & $\begin{array}{l}\text { Treated } \\
\text { group }\end{array}$ & 92 & 28 & 64 & $69.56 \%$ \\
\hline & & $\begin{array}{l}\text { Control } \\
\text { group }\end{array}$ & 107 & 82 & 23 & $21.49 \%$ \\
\hline \multirow[t]{2}{*}{4} & \multirow[t]{2}{*}{ Shotha } & $\begin{array}{l}\text { Treated } \\
\text { group }\end{array}$ & 68 & 11 & 57 & $83.82 \%$ \\
\hline & & $\begin{array}{l}\text { Control } \\
\text { group }\end{array}$ & 57 & 41 & 16 & $28.07 \%$ \\
\hline \multirow[t]{2}{*}{5} & \multirow[t]{2}{*}{ Crepitus } & $\begin{array}{l}\text { Treated } \\
\text { group }\end{array}$ & 57 & 11 & 46 & $87.17 \%$ \\
\hline & & $\begin{array}{l}\text { Control } \\
\text { group }\end{array}$ & 29 & 26 & 3 & $10.04 \%$ \\
\hline \multirow[t]{2}{*}{6} & \multirow[t]{2}{*}{ Tenderness } & $\begin{array}{l}\text { Treated } \\
\text { group }\end{array}$ & 85 & 20 & 65 & $76.47 \%$ \\
\hline & & $\begin{array}{l}\text { Control } \\
\text { group }\end{array}$ & 114 & 82 & 32 & $28.07 \%$ \\
\hline \multirow[t]{2}{*}{7} & \multirow[t]{2}{*}{ Nature of pain } & $\begin{array}{l}\text { Treated } \\
\text { group }\end{array}$ & 80 & 9 & 71 & $88.75 \%$ \\
\hline & & $\begin{array}{l}\text { Control } \\
\text { group }\end{array}$ & 85 & 59 & 26 & $30.58 \%$ \\
\hline \multirow[t]{2}{*}{8} & \multirow[t]{2}{*}{ Dosha dushti lakshan } & $\begin{array}{l}\text { Treated } \\
\text { group }\end{array}$ & 60 & 29 & 31 & $51.66 \%$ \\
\hline & & $\begin{array}{l}\text { Control } \\
\text { group }\end{array}$ & 53 & 36 & 17 & $32.07 \%$ \\
\hline
\end{tabular}

Relief in the symptom score was calculated with the help of percentage method. This showed percentage of relief in treated group was more as compare to control group. 
The effect of therapy in both group was evaluated with the help of score system .Hence non parametric test also used .The difference between before and after treatment was ranked and the difference was statistically analyzed with the help of Wilcoxon signed rank test and it showed significant result.

The mean angle of flexion in knee joint of treated group was $117 \pm 20.40$ and after treatment it increased up to $141 \pm 18.30$.the difference of mean was 24 it was analyzed statistically by paired t-test.the t-test value was 11.76 which was highly significant. In control group mean of the angle of flexion was $114 \pm 22.13$ and it also increased by $120 \pm 19.85$ and difference between these mean was statistically analyzed .t-value was 4.51

Routine blood test was estimated before and after treatment was statistically analyzed ,result was found insignificant ESR also statistically analyzed, it was reduced in treated group.

Radiological gradation showed insignificant result.

\section{Discussion:-}

Sandhigatavata is one of the Vataj Vyadhi and Asthyasrit Vyadhi,Acharya Charak has stated the Asthyashrit Vyadhi treatment as Panchakarma,Tikta Dravya and Ghrita. so we choose this Kshir. Sandhigatavata in the form of basti and ghrita was added 1/4 Of kshir.bhrihat panchamula are Vatashamak property and dominant in Tikta Rasa.Ghruta and Kshir are Jangam Sneha which is responsible for Snehan Karma.Kshir was given in the form of Basti which the best treatment ofVata Dosha.Basti introduced in Pakwashaya where Purishdharakala is present.Purishdhara Kala is nothing but Asthidhara Kala.Basti introduced in Pakvashaya,might be directly acting onAsthidhara Kala most important site of Vayu is Pakvashaya.by introducing Basti in Pakvashaya,it might also be alleviated Vayu.Ashraya Ashrayi bhava between Vayu and Asthi itself explain the action of basti on Sandhigatavata

\section{Conclusion:-}

All the symptoms of Sandhigatavata showed more significant result in treated group. Highly significant result in angle of flexion was found in this study .in hematological parameter there is no significant changes observed except ESR .so we concluded that Panchamuladi Kshir Basti effective in Sandhigatavata without any side effect.in this study we also found relief in patients who had cervical or lumbar spondolysis along with osteoarthritis, this will become further scope of study.

\section{References:-}

1. YadavyiTrikamji, editor, AyurvedDipika Sanskrit Commentary, CharakSamhita, ChaukhambaPrakashan 2013

2. MS Radha, mr,gangadhar,prevalence of knee OA patients,IJRSC vol issue April 2015

3. DL kasper,E braunwald,J.L.Harrisons, principle of internal medicine, $17^{\text {th }}$ ed.

4. YadavyiTrikamji, editor, AyurvedDipika Sanskrit Commentary, CharakSamhita, ChaukhambaPrakashan 2013.

5. Chakradatta Samhita,savimarsha bhavmishra sandipani hindi vyakhya vyakhyakar-jagdishwar Prasad tripathi.

6. Sushrut Samhita, Chaukhamba prakashan ,1980

7. Tripathi Brahmanand. Sharangdhar Samhita. Reprint Edition 2007. Varanasi. Chaukhambha Surbharati Prakashan. Madhyam Khand/12/5. 